ББК 67.402

DOI: 10.14451/2.155.36

УДК 34

\title{
ОСОБЕННОСТИ ПРИМЕНЕНИЯ БЮДЖЕТНЫХ ПРОЦЕССУАЛЬНЫХ НОРМ О ПРЕДОСТАВЛЕНИИ ГРАНТА (СУБСИДИИ) АРБИТРАЖНЫМИ СУДАМИ РОССИЙСКОЙ ФЕДЕРАЦИИ
}

\author{
(C) 2021 Федотова Анна Александровна \\ аспирант кафедры финансового, банковского и таможенного права \\ имени профессора Нины Ивановны Химичевой \\ Саратовская государственная юридическая академия, Россия, Саратов \\ E-mail:Ann_kach92@mail.ru
}

В статье рассматриваются проблемы судебной правоприменительной практики применения бюджетных процессуальных норм в сфере субсидирования юридических лиц и индивидуальных предпринимателей. Анализ правоприменительной практики свидетельствует о том, что субсидирующие органы в рамках проведения контрольных мероприятий зачастую неверно трактуют положения Соглашений о предоставлении субсидий во взаимосвязи с положениями действующих законодательных актов, в связи с чем арбитражными судами формируется практика по обоснованности признания контролирующими органами действий получателей субсидии в качестве нарушений, являющихся основаниями для возврата средств субсидии.

Ключевые слова: применение бюджетных процессуальные норм, условия предоставления субсидии, условия использования средств субсидии, нецелевое расходование бюджетных средств, принцип эффективности (результативности) использования бюджетных средств.

Анализ статистических сведений о работе арбитражных судов субъектов Российской Федерации свидетельствует об относительно не большом количестве споров, вытекающих из бюджетных правоотношений [1]. Однако, анализ судебной практики приводит к выводу о сложности и неоднозначности применения отдельных бюджетно-правовых норм, что неизбежно приводит к нарушению принципа единообразия судебной практики.

В рамках настоящего исследования предлагается обратить внимание на проблемы применения бюджетного законодательства при рассмотрении арбитражными судами споров, вытекающих из отношений по предоставлению грантов и субсидий из средств федерального, регионального или местного бюджета в рамках реализации соответствующих национальных целевых программ.

В финансово-правовой науке сложилось мнение о том, что «средства бюджета предоставляются физическим и юридическим лицам частно-правового статуса в рамках гражданскоправовых отношений» [2, С.89]. Однако из анализа судебной практики следует, что не смотря на то, что предоставление субсидии юридическим лицам и индивидуальным предпринимателям осуществляется на основании Соглашения, обладающего признаками гражданско-правового договора, тем ни менее при рассмотрении споров в сфере субсидирования суды применяют бюджетные процессуальные нормы, содержащиеся не только в Бюджетном кодексе РФ, но и в актах законодательных (исполнительных) органов субъектов РФ, определяющих порядок предоставления субсидий и грантов. Кроме того, не смотря на то, что в силу положений ст. 30 БК РФ получатели субсидий и грантов не являются получателями бюджетных средств, в отношении них проводятся контрольные мероприятия с применением бюджетных процессуальных норм не только по поводу соблюдения условий Соглашения, но и по проверке целевого расходования средств субсидии, которые по своей правовой природе являются средствами соответствующего бюджета.

Применение статей 38, 289, 306.1 Бюджетного кодекса Российской Федерации обусловлено тем, что ими регулируется принцип целевого расходования бюджетных средств, действие которого не ограничивается правоотношениями, складывающимися только между участниками бюджетного процесса [3].

Таким образом, приходим к выводу о том, 
что правовое регулирование отношений в сфере субсидирования хозяйствующих субъектов за счет средств соответствующих бюджетов бюджетной системы РФ носит смешанный характер.

Предоставление субсидий юридическим лицам, не являющимся государственными (муниципальными) учреждениями, а также индивидуальным предпринимателям и физическим лицам регулируются статьей 78 Бюджетного кодекса РФ (далее - БК РФ), многочисленными Постановлениями Правительства РФ об утверждении Правил предоставления субсидий и нормами регионального законодательства, которые должны соответствовать требованиям, установленным Правительством РФ.

Поскольку в Российской Федерации активно используется программно-целевой метод ведения хозяйства с применением правил бюджетирования ориентированного на результат, то расходование бюджетных средств должно осуществляться в строгом соответствии с действующими программами, для реализации которых в законе о бюджете на очередной финансовый год и плановый период запланировано выделение денежных средств. При этом следует обратить внимание на то, что использование правил бюджетирования, ориентированного на результат направлено на достижение максимального результата, предусмотренного той или иной целевой программой с наименьшими финансовыми затратами. Данный постулат закреплен в статье 34 БК РФ и именуется как принцип эффективности (результативности) использования бюджетных средств.

В соответствии с положениями статьей 28 , 38,78 и 306.4 Бюджетного кодекса РФ в качестве принципов предоставления субсидии или гранта в форме субсидии выступают эффективность расходования бюджетных средств, адресность, целевой характер, безвозмездность и безвозвратность. Исключением из принципа безвозвратности являются нарушения со стороны получателей субсидии, которые могут повлечь обращение уполномоченных органов с требованиями о возврате субсидии или привлечение к административной ответственности [4].

При этом законодатель разграничивает понятия «эффективность» и «результативность» использования бюджетных средств. Под эффективность понимается «достижение заданных результатов с использованием наименьшего объема средств», а под результативностью - «до- стижение наилучшего результата с использованием определенного бюджетом объема средств».

Указанные выше нормы, в совокупности с региональными нормативными правовыми актами, регулирующими правила предоставления субсидии (гранта в форме субсидии) и условиями соглашений о предоставлении субсидии в своем системном толковании имеют определяющее значение при рассмотрении требований уполномоченных органов о возврате субсидии, предоставленной юридическому лицу или индивидуальному предпринимателю.

В соответствии с п. 3.1. ст. 78 БК РФ основанием для возврата средств предоставленной субсидии является нарушение условий ее предоставления. При этом из смысла рассматриваемой правовой нормы следует, что условия, правила и порядок предоставления субсидии регламентируются бюджетными процессуальными нормами, установленными региональным законодателем [5] с учетом общих требований [6] и соглашением о предоставлении субсидии [7], заключенным между главным распорядителем бюджетных средств областного бюджета и получателем субсидии.

Отдельно следует обратить внимание на объективную необходимость в разграничении понятий «условия предоставления субсидии» и «условия использования средств предоставленной субсидии» [8, С.51-59], поскольку это имеет важное правоприменительное значение. Условия предоставления субсидии - это регламентированные региональными бюджетными процессуальными нормами критерии, которым должно отвечать лицо, претендующее на получение субсидии, в том числе с учетом требования целевых программ различного уровня. Например, лицо не должно осуществлять предпринимательскую деятельность в течение определенного времени [9], не должно иметь задолженностей перед бюджетом [10], должно предоставить полный пакет документов, необходимых для рассмотрения вопроса о предоставлении субсидии, содержащего достоверные сведения [11], иметь определенный объем собственных средств и т.д. В то время как условия использования средств предоставленной субсидии - это регламентированные региональными бюджетными процессуальными нормами и соглашениями главного распорядителя бюджетных средств и получателя субсидии правила использования (расходования) средств уже предоставленных юридическому лицу или 
индивидуальному предпринимателю. Например, достижение установленных показателей эффективности (результативности) расходование предоставленных средств субсидии [12], своевременное осуществление мероприятий, предусмотренных бизнес-проектом, своевременное предоставление отчетности об использование субсидии и т.д. Разграничение рассматриваемых категорий следует проводить и с учетом этапов развития правоотношений. Так, например, на стадии проведения конкурса, отбора претендентов на получение субсидии, проверяется их соответствие условиям предоставления субсидии, однако условия о достижении определенных результатов хозяйственной деятельности следует относить к этапу проведения контрольных мероприятий по проверке законности использования полученных средств субсидии. В этом случае, не достижение получателем субсидии установленных порядком предоставления субсидии и соглашением о предоставлении субсидии плановых показательней эффективности (результативности) использования бюджетных средств будет вполне правомерно выступать в качестве основания применения ответственности в форме возврата средств субсидии. Так, например, Арбитражным судом Центрального округа, отменяя акты судов нижестоящих инстанций по иску Министерства к Обществу о взыскании суммы субсидии ввиду нарушения условий и порядка предоставления субсидии, выраженного в непредставлении предусмотренной Соглашением отчетности, обратил внимание на следующие обстоятельства. Условия $u$ порядок предоставления субсидий регламентированы Порядком предоставления субсидии и определяет перечень документов, предоставляемых получателями субсидий для получения субсидий, $a$ также требования к указанным документам, в том числе по их форме, составу, достоверности. Обществом такие документы были представлены, а Министерством приняты и рассмотрены. Нарушение Общества состоит в бездействии по отношению к обязанности по последующему представлению отчетности.

При этом предоставление отчетности имеет своей задачей способствовать контролю уполномоченным органом за выполнением получателем субсидии показателя результативности ее использования. В свою очередь не представление отчетности в установленные соглашениями сроки, не является нарушением ни условий, ни поряд- ка предоставления субсидии, и, как следствие, не может служить основанием для применения такой санкции как возврат субсидии, исковые требования удовлетворению не подлежат [13].

По иному делу Министерством в качестве нарушения целей, условий и порядка предоставления субсидии было признано не представление Предпринимателем копии документа, подтверждающего проведения агрохимического обследования земель, признаваемой обязательной для предоставления субсидии, хотя цели и установленные показатели были им достигнуты. Однако Арбитражным судом Центрального округа была поддержана позиция суда апелляционной инстанции о том, что предоставление копии документа, подтверждающего проведения агрохимического обследования земель, имеет своей задачей способствовать контролю уполномоченным органом за выполнением получателем субсидии показателя результативности ее использования. В связи с чем судом кассационной инстанции был сделан вывод о том, что допущенное нарушение установленного порядка предоставления субсидии имеет формальный характер, требования об ответственности за нарушение (бездействие предпринимателя по отношению к обязанности по предоставлению документа об обследовании земель) несоразмерны объему заявленных требований [14].

Следует отметить, что в некоторых случаях, не достижение показателей на момент проведения контрольных мероприятий, судами также не расцениваются в качестве нарушений, влекущих возврат средств предоставленной субсидии. Так, например, Предпринимателем на момент проведения контрольных мероприятий, не были достигнуты установленные Соглашением показатели результативности ввиду значительного повышения ценн на топливо, электроэнергию, строительные материалы, корма, витамины, лекарства, а также в связи с существенным снижением закупочных цеен на производимую продукцию (молоко и мясо). По результатам проверки было установлено, что существенная часть мероприятий по расходованию средств гранта была выполнена, за исключением достижения показателей. Фактически животноводческая ферма создана и функционирует, имущество, приобретенное для ее развития, используется по целевому назначению, ответчиком предпринимаются меры, направленные на достижение показателей прироста количества содержащихся на ферме 
крупного рогатого скота, увеличения объема производства животноводческой продукции и выручки от ее продажи. Данные обстоятельства судом расценены как добросовестное поведение Индивидуального предпринимателя. Судом сделан вывод о том, что поскольку условие о возврате гранта в случае нарушения грантополучателем порядка его использования по своей природе является ответственностью и обеспечивает исполнение обязательства и/или восстановления нарушенного права, то и нормы, устанавливающие порядок предоставления и правила расходования гранта, подлежат истолкованию с учетом защищаемого этой нормой законного интереса.

Принимая во внимание принципы и цели предоставления гранта - безвозвратное и безвозмездное софинансирование затрат глав КФХ, связанных с развитием семейных животноводческих ферм, применение к получателю субсидии мер ответственности в виде ее возврата допустимо лишь в случае существенного нарушения последним предусмотренных соглашением обязательств и (или) прав уполномоченного органа, производящего выделение денежных средств, в результате совершения умышленных недобросовестных действий (бездействия), противоречащих смыслу и направленности такого соглашения. В рассматриваемом случае при выявленных истиом нарушениях формального характера ответчик в случае возложения на него обязанности вернуть субсидию будет поставлен в неравные условия с грантодателем, а уже достигнутый общественно полезный результат предоставления гранта бу- дет нивелирован.

Таким образом, в судебной правоприменительной практике рассмотрения споров, вытекающие из бюджетных правоотношений в сфере субсидирования можно выделить две разновидности направления нарушений, являющихся основаниями для возврата средств полученной субсидии: ввиду нарушений условий предоставления субсидий (субъектами нарушения могут выступать не только получатели субсидии, но и субсидирующие органы [15]) и нарушений условий использования средств предоставленной субсидии (субъектом нарушения выступает получатель субсидии).

Из приведенных в настоящем исследовании примеров видно, что финансовыми органами при применении бюджетных процессуальных норм о целях, правилах и порядке предоставления субсидий (грантов) с учетом положений о целевом использовании бюджетных средств, установленных Бюджетным кодексом РФ термины «условия предоставления субсидии» и «условия использования средств предоставленной субсидии» отождествляются, в то время как, органами судебной власти проводится их разграничение с учетом конкретных обстоятельств дела. Следовательно арбитражный суд при рассмотрении спора, вытекающего из бюджетных правоотношений в сфере субсидирования, не только применяет бюджетные процессуальные нормы, но и приводит их системное толкование во взаимосвязи с условиями Соглашений о предоставлении субсидии (гранта в форме субсидии).

\section{Библиографический список}

1. Количество рассмотренных дел, вытекающих из бюджетных правоотношений в 2016 году составило 3826 дел, в 2017-3577 дел, в 2018-4089 дел, в 2019-3776 дел (данные Судебного Департамента при Верховном Суде РФ).

2. Пешкова Х.В.Бюджетное устройство России: монография / Х.В.Пешкова.- Москва: ИНФРА-М, 2017.С.89; Сперанская Л. В. Договор целевого финансирования // СПС КонсультантПлюс. 2020 (дата обращения: 20.05.2021).

3. Определение Верховного Суда РФ от 18.09.2017 № 306-КГ17-12478 по делу № А55-5613/2016 // Картотека арбитражных дел.URL.: https://kad.arbitr.ru (дата обращения: 20.05.2021).

4. Бюджетный кодекс Российской Федерации. Федеральный закон от 31.07.1998 № 145-Ф3 (ред. от 08.06.2020) // Собрание законодательства РФ, 03.08.1998, № 31, ст. 3823.

5. Например, Постановление правительства Воронежской области от 30.04.2019 № 458 «Об утверждении Порядка предоставления грантов «Агростартам» в форме субсидий из областного бюджета на создание и развитие крестьянских (фермерских) хозяйств». 
6. Об общих требованиях к нормативным правовым актам, муниципальным правовым актам, регулирующим предоставление субсидий юридическим лицам (за исключением субсидий государственным (муниципальным) учреждениям), индивидуальным предпринимателям, а также физическим лицам - производителям товаров, работ, услуг. Постановление Правительства РФ от 06.09.2016 № 887 (ред. от 26.12.2019) // Собрание законодательства РФ, 12.09.2016, № 37, ст. 5506.

7. Об утверждении типовых форм соглашений (договоров) о предоставлении из федерального бюджета субсидии юридическим лицам (за исключением государственных учреждений), индивидуальным предпринимателям, физическим лицам - производителям товаров, работ, услуг. Приказ Минфина России от 31.10.2016 № 199н (ред. от 08.10.2019) (Зарегистрировано в Минюсте России 06.12.2016 № 44584) // Официальный интернет-портал правовой информации http://www.pravo.gov.ru (дата обращения: 20.05.2021).

8. Герасименко Ю.В., Сынтин А.В. Правила предоставления субсидий субъектам малого и среднего предпринимательства: проблемы и перспективы совершенствования // Современное право. 2018. № 10. С. 51-59.

9. Например, Постановление Арбитражного суда Северо-Кавказского округа от 06.09.2020 по делу № А222520/2019// Картотека арбитражных дел.URL.: https:/kad.arbitr.ru (дата обращения: 20.05.2021).

10. Постановление Арбитражного суда Западно-Сибирского округа от 08.06.2020 по делу № A75-8940/2019// Картотека арбитражных дел.URL.: https://kad.arbitr.ru(дата обращения: 20.05.2021).

11. Постановление Арбитражного суда Центрального округа от 08.06.2020 по делу № А62-2652/2019// Картотека арбитражных дел.URL.: https://kad.arbitr.ru(дата обращения: 20.05.2021).

12. Решение Арбитражного суда Воронежской области от 11.11.2019 по делу № А14-13707/2019// Картотека арбитражных дел.URL.: https://kad.arbitr.ru(дата обращения: 20.05.2021).

13. Решение Арбитражного суда Республики Крым от 01.08.2018 по делу № А83-12308/2018 // Картотека арбитражных дел.URL.: https://kad.arbitr.ru(дата обращения: 20.05.2021).

14. Постановление Арбитражного суда Центрального округа от 01.06.2020 по делу № А83-7670/2019 // Картотека арбитражных дел.URL.: https://kad.arbitr.ru(дата обращения: 20.05.2021).

15. Например, Решение Арбитражного суда г. Москвы от 27.05.2019 по делу № a57-11376/2019 // Картотека арбитражных дел.URL.: https:/kad.arbitr.ru (дата обращения: 20.05.2021); Постановление Арбитражного суда Поволжского округа от 18.08.2020 по делу № A12-39358/2019 // Картотека арбитражных дел.URL.: https:// kad.arbitr.ru (дата обращения: 20.05.2021). 